\title{
Impact of Job Design on Employee Performance, Mediating Role of Job Satisfaction: A Study of FMCG's Sector in Pakistan
}

\author{
Nisbat Ali $^{1} \&$ Muhammad Zia-ur-Rehman ${ }^{2}$ \\ ${ }^{1}$ National University of Modern Languages Islamabad, Pakistan \\ ${ }^{2}$ National Defence University, Islamabad, Pakistan \\ Correspondence: Dr. Muhammad Zia-ur-Rehman, Professor of Management Sciences at National Defence \\ University Islamabad, Pakistan. E-mail: Scholarknowledge@gmail.com or Nisbat.mna@gmail.com
}

Received: October 13, 2013

Accepted: December 2, 2013 Online Published: January 20, 2014

doi:10.5539/ijbm.v9n2p70

URL: http://dx.doi.org/10.5539/ijbm.v9n2p70

\begin{abstract}
The present study intends to measure the effect of job design on employee performance while the mediation effect is job satisfaction, although the job design has several methods but we use JCM model (Oldman \& Hackman, 1976), which has five dimensions of Job Characteristics Model (skill variety, task identity, task significance, job autonomy and feedback) on employee performance. We have conducted this survey because nearly all companies working in FMCG industry are multinational; they are following the same procedures and policies of their parent company with minute change accordingly Quantitative method of research was adopted and received $90 \%$ responses out of 150 sample size. Findings of the present research indicate a positive relationship between job design and employee performance. While the mediating effect of Job satisfaction is also found having a positive effect on employee's performance. Organizations always have quest of finding the unique ways in order to enhance the performance of the employees, this research would help to analyze that how an adequate job design would help to increase the employee performance.
\end{abstract}

Keywords: job design, employee performance, employee satisfaction, job characteristic model (task identity, task significance, skill variety, task autonomy, feedback)

\section{Introduction}

A broad definition of Job design would encompass disclosure by scholars have customarily describes jobs as set of tasks which is deliberated plan to be accomplish by one employee and tasks in simple words is the allocation of small patches of work to an employees who have been accomplish it within the given time period (Griffin, 1987). Grant (2007) further elaborate tasks as the fundamental and essential bases of jobs that neglect the reality that jobs are intended with highly structured relational mechanism that impacts not only employee's interpersonal relations but associations as well. Business Leaders always motivate the people that they should pursue a collaborative work design in which they make sure that employees should be responsible for their work performance (Tanner, 1998). It is found that sometimes the imminent bond of job and goals setting can help to enhance the level of performance and the design of job can increase not merely the satisfaction but also the worth of performance as well (Garg \& Renu, 2005). Job design and related concepts has rooted back to 1900. When many pioneers of scientific management had explore new ways about the business ideology like Taylor (1947), Gilbreth (1911) systematically exam the jobs with numerous methods and techniques but all of these consider job design is the most important in the scientific management. The first ever theory was presented related to individual job design that was two factor theory (Herzberg, Mausner, \& Snyderman, 1959) which basically describe two types of the motivational factors. One is related to intrinsic motivation (e.g. authority, achievement and self recognition) and other is a hygiene factor, which describes to extrinsic motivation of individual work (e.g. salary. working environment and other fringe benefits).

Huselid and Becker (1997) maintain that operational excellence emanates from human resource management systems that also generate financial gains in organizations with the help of job design and its imminent goals ahead. It depends on nature of the job, some required role performance which is found highly recurring on the other and, some other jobs display dominant flexibility in the tasks to be executed (Mueller, Boyer, Price, \& Iverson, 1994). In addition to it, job design includes perceived work demands, job control and social support that lead to higher output (Love \& Edwards, 2005). As many human resources professionals have discovered that there is strong 
impact of job design on the productivity and the motivation and job satisfaction of employees in an organization. In order to avoid these issues, it is pertinent to look for alternative strategies and approaches to job design which includes job enrichment, job engineering, quality of work life, socio technical designs, the social information processing approach (SIPA) and the job characteristics approach (Garg \& Renu, 2005). Very thin material is available on the job design in FMCG sector, so managers in Pakistan could not find out the ways to enhance the performance of employees. Composition of FMCG's in GDP of Pakistan is 23.6\% (Indexmundi, 2011). Job design is one of the major components for employee performance. Employers and company's managers are always looking for opportunity and alternatives, which can increase employee satisfaction because performance of workers is dependent (along with other things) on the level of satisfaction on job in the organization. Meanwhile company's objectives and mission is also reliant of employee's performance. Designing jobs and roles appropriately is very imperative in elevating the performance of employees, which is addressed through Job characteristic model. So this motivates us to test that how job design can enhance the performance of the employees. The concept further explores by Hackman and Oldham's (1976) through job characteristics model, which describe more specifically about the individual job design, it also identifies five core dimensions which are skill variety, task identity, task significance, autonomy and feedback. It added more value and practical approach to the job design with changing circumstance.

\section{Literature Review}

\subsection{Job Characteristic Model}

With the employees perspective for the perceived task Job characteristic model (Hackman \& Oldham, 1975) is commonly used. The model has five important dimensions, which is skill variety, task identity, task significance, autonomy and feedback. According to Garg and Rastogi (2005) skill variety is the degree of utilization of different skills and abilities. Skill variety is the extent of diversity in any task of the occupation (Price \& Mueller, 1986). Researcher argues that the claim for skills in the economy is originated from the goal /aim requirements related with jobs (Cappelli, 1993). Skill variety is one factor in the job characteristics model that influences the knowledgeable meaning of work (Hackman \& Oldman, 1980). In research task variety is seen as a number of different task elements required in the job fulfillment (Harvey, 1991). Task variety possibly will transmit explicit and declarative knowledge (Pentland, 2003). From the perspective of career literature, an individual in the beginning of his/her career try to discover tasks in which they will be obtained successful goal (Feldman \& Thomas 1992). Individuals dynamically deal with their career (flexibly career oriented); guest worker sales persons are also expected to perceive that high job variety (different skill) can be a source to help for their career growth during the beginning stage of the profession (Baird \& Kram 1983). Career advantages will perhaps increase their job satisfaction, (Flaherty \& Pappas 2002). Intrinsic job characteristics, such as skill variety and significance of task, are normally associated with low absenteeism (Taber \& Taylor, 1990). The research study explore that the skills and knowledge are particular required by information system (IS) experts to do their job perform effectively. Task identity is the amount to which a job demands for the accomplishment of a given task that is considered its commencement with the desired outcome and if the task has no identity than employee will not be motivated for the drama of the task (Locke \& Edwin 1981). Task identity required a pragmatic action to complete 'whole' task; responsibility of job completion of job from its start to end with visible result. Complex task and difficult goal can better perform due to the effect of both cognitive and motivational processes (Campbell \& Gingrich, 1986). Researcher emphasized that skill and knowledge are main requirement of complex task (March \& Simon, 1958) but others have separately focused on different performance magnitude include in a task (Latham \& Yukl, 1975).

Some researcher view has given emphasis to psychological implication of complex tasks (Pierce \& Dun-ham, 1976). Role of stress has negative relation with sales force job satisfaction because of role conflict and role ambiguity (Bagozzi \& Richard, 1978). However role clarity have a positive relation with job satisfaction (Donnelly, James, Ivancevich \& John 1975). Task significance is a very important element of JCM according to study of Hackman and Oldham's (1975) is defined as it is the extant in which job has a effect on the life of the people. Another study describe that the worth of the task depend on internal and external significance. It maintains that both internal significance that how a task is valuable for the organization and external significance is equally important. The image of job in the minds of people and employees, bears significant substance to see that how much he feels proud while describing his job in the public (Garg \& Rastogi, 2005). Standard job performance states the degree to which a management employee accomplish organizationally prescribed work role prospects (Katz \& Kahn, 1966). In order to get efficiency at workplace, inventive job performance considered as critical element for organizations (Kanter, 1988). Long overdue, job performance theories have finally originated to mark their contribution in the executive literature (Motowidlo, Borman, \& Schmit, 1997). Activation theory proposes 
that transitional rather than low or high levels of quantifiable job demands

benefit job performance and job satisfaction amongst managers (Gardner, 1986). Managers perform better and feel more pleased in response to transitional levels of job demands wherever they recognize effort-reward fairness than managers who recognize "under reward unfairness (Janssen, 2001). Research in psychology and organizational behavior proposes that individual job performance's effect by characteristics of the work environment might, in turn, interact with employees' personal characteristics (Hyatt \& Prawitt, 2011). When we observe the analysis based on the total population, it provides no valid and precise results as analyses of the job characteristics-performance relationships in different situations or varying subcategories in the population provided (Fried \& Ferris, 1987). All the job characteristics except for feedback from coworkers and from others are positively correlated to the measures of satisfaction and performance (Brass, 1981). Good training and development creates learning organizations, resulting in quantifiable performance and enhance organizational performance (Niazi, 2011). Task autonomy is extent in which an individual given a freedom, choice and liberty to precede a task, such as self time management for a task and the way to be done (Hackman, 1980). Lawler, Mohrman, and Ledford (1995) was claim that Task autonomy and related forms of employee contribution in the task were found effective in ninety percent of Fortune companies out of one thousand. If the task autonomy was given to the employee, it may see wonderful results and the high level of satisfaction and performance (Dwyer, Schwartz, \& Fox, 1992). Empirical evidence had been found that both autonomy need and achievement need manipulate on the individuals' responses to task autonomy (Orpen, 1985). The higher degree of control a person has over his job will lead to the higher level of satisfaction and performance because the work shows his own decisions (Kouzes \& Posner, 1995). Nancy and Daniel (1996) conclude that remarkable improvement can be seen with the immediate impact of both, the feedback and the workers' ability to structure the work, whether working independently or in teams. Certain jobs and goals setting can enhance the level of performance and the design job can increase satisfaction at the same time, the quality of performance as well (Garg \& Rastogi, 2005). Evidence found that representing that task-related feedback is positively correlated with motivation, satisfaction, and performance in virtual teams (Geister, Konradt \& Hertel, 2006). In the current study we test the following hypothesis in the context of Pakistani organization.

Performance measurement is seen as a tool for feedback in the management paradigm, which in turn acts as a contrivance for program improvement (Mausolff, 2004). In order to enhance individual performance, feedback channels play significant part in organizations (Elkins \& Phillips, 2000). Moreover, this feedback can yield productive result in the development of employees' attitudes and conduct (Lam, Yik \& Schaubroeck, 2002). Favorable feedback can be taken as an additional motivation in employees to accomplish their career targets (Lowry, 1994). Feedback is an important job characteristic that boosts a person intellectual ability of the mind and used to control his or her behavior by having internal control over it. Self-control

Lets a person to monitor and control his/her behavior by their own With the rise of organizational learning as a management paradigm, there is greater interest in the potential of performance measurement to function as a feedback contrivance for program improvement (Mausolff , 2004). Educating individuals with performance feedback is beneficial to both organizations and individual's performance (Elkins \& Phillips, 2000). Performance feedback can play a vital role in the enhancement of employees' attitudes and behaviors. Favorable feedback contributes towards an additional motivation in employees to achieve their career goals (Lowry, 1994). Feedback thus is a consequence of performance (Hattie \& Timperley, 2007). Feedback is vital to learning. Simple task repetition is not an effective strategy, unless having knowledge of results (Thorndike, 1931). Managers received hostile feedback for job demands and negative outcomes as compared to managers who had not received hostile feedback (Emmerik, Bakker, Martin \& Euwema, 2008). Employees can better contribute in goal performance and in the exploitation of plans through positive and constructive feedback. Employees contributes towards training in a reasonable \& effective way if employees equip through knowledge of what standard performance is all about \& then compare it with standard, via assessment and feedback (Kluger \& DeNisi, 1996). People, who receive positive feedback, try it to do the same thing again and again as to those who receives negative feedback and they are unlikely to try it again and perhaps discover new approaches. Sometimes receiving feedback often originally provoked an inundation of emotions by damaging their self-respect and sometimes forcing them to confront some of their deepest worries and lack of confidence.

\section{H1: Job Design is significantly related with Employee Performance.}

\subsection{Job Characteristics and Employee Satisfaction}

According to Brief (1998) if an employee's work is attractive and his pay is reasonable, his promotional opportunities are fair enough to exhale in the job, his supervisors and colleagues are encouraging him to attain task 
outcomes then a such type of situational approach may forecast that he is satisfied with his job. However job satisfaction is based on the particular task environment concluded by Locke's (1976). Furthermore the concept of job characteristics has received the more pragmatic consideration as interpreter of employee job satisfaction (Glisson \& Durick 1988). Job Diagnostic Survey (JDS) developed by Hackman and Oldham (1975) was taken to determine job characteristics and job satisfaction. Statistical analysis predicted that each of the five job characteristics i.e. Skill variety, task significance, task identity, autonomy and feedback were positively related to job satisfaction and organizational commitment.

Spreitzer (1999) found that the job design was related to the satisfaction for both employee and organization as a motivating factor by majority of employees. Adler (1991) found that systems in which employees reported higher perceptions were of skill variety, task significance, autonomy, and feedback reported higher levels of satisfaction and internal work motivation.

H2: Job Design is significantly related with Employee Satisfaction.

\subsection{Job Characteristics and Employee Performance}

Fried and Ferris (1987) had been concluded in their met analysis that job characteristic model has a significant impact on not only job performance but job satisfaction as well. This poor performance in organizations depends mainly in individual intention to work and give his full strength to organization to boast its performance and improve results those are relating directly and indirectly to different people and organization and ultimately country economic state (Ryan, Schmit \& Johnson, 1996). Certain jobs and goals setting can enhance the level of performance and the design job can increase not merely the satisfaction but the quality of performance as well (Garg \& Rastogi, 2005). It depends on nature of the job some required role performance, which is highly repetitive while the other jobs have a dominant degree of variety in task and they are executed (Mueller, Boyer, Price \& Iverson, 1994). Standard job performance states the degree to which a management accomplishes prescribed work role prospects by an organization (Katz \& Kahn, 1966). In order to get efficiency at workplace, inventive job performance considered as critical element for organizations (Kanter, 1988). Long overdue, job performance theories have to end with their contribution into the organizational literature (Campbell, 1990). Activation theory proposes that transitional rather than low or high levels of quantifiable job demands benefit job performance and job satisfaction amongst managers (Gardner, 1986). Managers perform in a better way and feel more pleased in response to transitional levels of job demands wherever they recognize effort-reward fairness than managers who recognize "under reward unfairness (Janssen, 2001). Different research studies conducted in the field of Psychology and Organizational Behavior propose that individual job performance gets affected by characteristics of the work environment, which may in turn interact, with employees' personal characteristics (Hyatt \& Prawitt, 2011). In this regard, analysis based on the total population provides no valid and precise results as analyses of the job characteristics-performance relationships in diverse situations or different subcategories in the population provides. All the job characteristics except for feedback from coworkers and from others are positively correlated to the measures of satisfaction and performance (Brass, 1981). As Motowidlo et al. (1997) suggest, performance "flows on seamlessly" majority of us act as preservers in treating it as a motionless incident, therefore our attempts to create true representations of these behavioral systems will be gradually undermined. Good training and development creates learning organizations, resulting in quantifiable performance and enhance organizational performance (Niazi, 2011).

H3a: Employee Satisfaction is positively and significantly related with Employee Performance.

H3b: Job satisfaction has a mediating effect between job design and job performance. 


\subsection{Theoretical Framework}

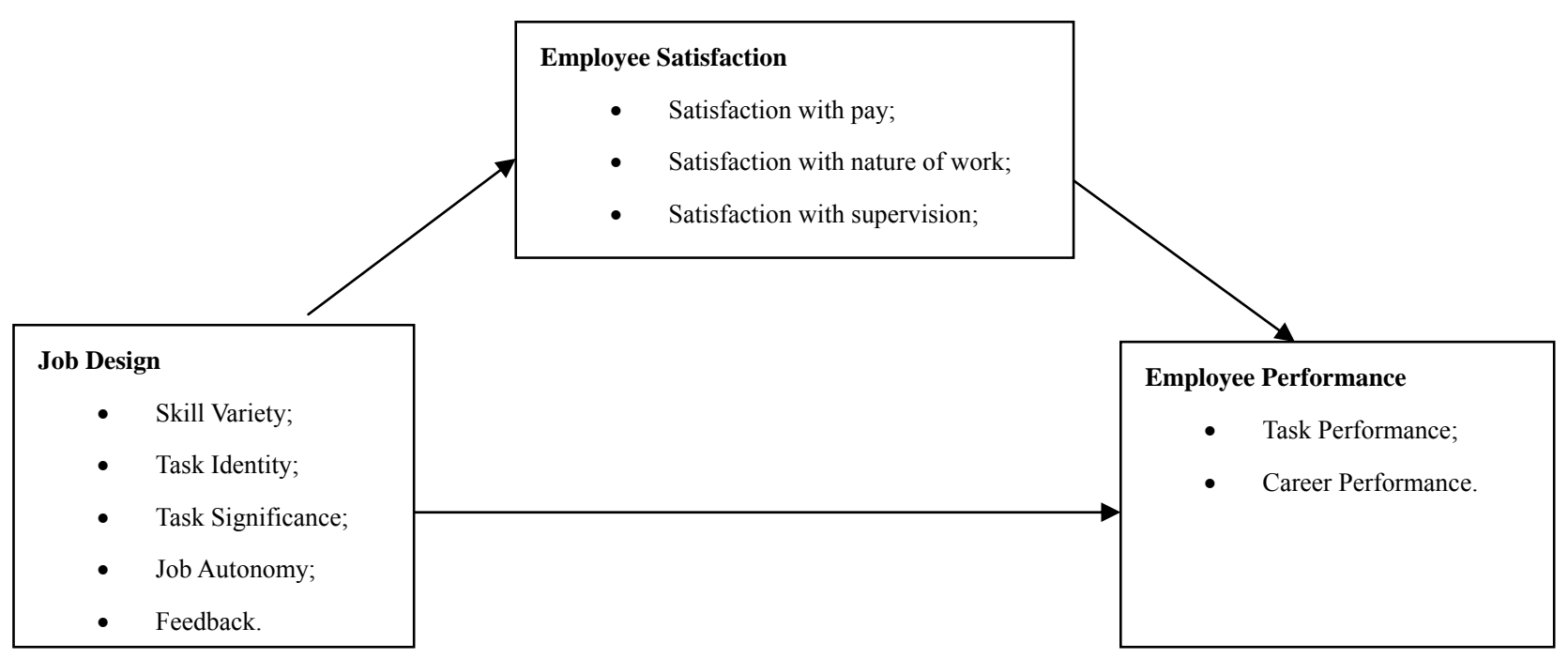

Figure 1. Theoretical framework

\section{Methodology}

\subsection{Samples and Data Collection Method}

The main objective of this research study is to find out the impact of job design on employee performance while the mediating effect is job satisfaction. In order to prove this relationships we have conducted this survey because nearly all companies working in FMCG industry are multinational; they are following the same procedures and policies of their parent company with minute change accordingly Quantitative method of research was adopted and received $90 \%$ responses out of 150 sample size. Further the questionnaire has two sections, in first section the Respondents were asked about the demographic aspects like questions on gender, age, department and tenure. Five-point liquid scale was used to collect the responses of respondents.

Before asking them to fill the questionnaires, the respondents were informed briefly about the importance of the present research.

\subsection{Measures and Validity}

Questionnaire was developed and used in the data collection phase and several measures were taken from Sims, Szilagyi, and Keller (1976) who used 30 measures, which were broken into different categories of job variety, autonomy, and task identity. Co efficient alphas of the subscales for variety, autonomy, and identity range from 0.76 to 0.84 . These measures were also used by Aryee, Chay and Chew in 1996, Dodd and Ganster (1996), Ganzch (1998), Mathieu and Hofmann and Farr (1993), Williams, Gayin and Williams (1996). The task significant, job variety and task identity measures were taken from MJDQ (Multi method job design questionnaire) by Campion (1988). The Co efficient alphas of the subscales for task significant range from 0.75 to 0.89 . The validity of job autonomy correlated negatively with specialization, job variety was correlated with standardization, (Matthew et al., 1993). Dodd and Gansters 1996 found that objective job measures correlated positively with employee perceptions of job obtained with the job characteristics inventory.

\section{Data Analysis}

\subsection{Test of Hypothesis}

Based upon the comprehensive review of the literature and hypothesis we rum the regression and correlation analysis (Table 2,3). Before this in table 1 we analysis the demographics through frequencies of their occurrence. Mediation affects also shown in tables. According to the demographic table1 it is stated here that majority of the respondent is lies between $21-30$ that is $38.9 \%$, while the respondent at the age of $21-25$ are $26.4 \%$. Which also shows that the major work force in FMCG's sector lies between 26 to 30. Table 2 as the correlation table shows the impact of job satisfaction on Job performance is $0.619^{* *}$ which is significant at level of .01 . On the other hand job design has also very substantial impact on job performance according to our 
analysis, which is $0.492 * *$ it means it is significant.

The result of the first hypothesis based on the correlation was positive $\left(0.492^{* *}\right)$. So job design has positively and significantly related with employee performance. Based upon the third hypothesis (H3), in order to study the impact of mediating on job satisfaction, Baron and Kenny (1986) proposed a three-step procedure, which was adopted for the analysis. Zboja and Voorhees (2006) have also used the same procedure to prove the role of mediating effect in their research. So according to the process it has three steps, the first one is the significance test between of the relationship between independent variable (job design) and mediating (Job satisfaction), so in the first step the relation was found positive and significant $(\mathrm{p}>0.01)$. The next step demanded a test of relationship between the independent variable (Job design) and the dependent variable (Job performance). So a final point, in the very next step $\left(3^{\text {rd }}\right)$ the dependent variable desired to be regressed on the mediator. To legitimize mediation the independent variable and the third step should determine the mediator to be significantly related to the dependent variable and it is very important that the effect of the independent variable on the dependent variable should be less than the effect it had in the second step. So in our case it proves full (0.302) mediation.

Table 1. Demographics

\begin{tabular}{lll}
\hline & Description & Percentage \\
\hline Age & $21-25$ & 26.4 \\
& $26-30$ & 38.9 \\
& $31-35$ & 29.9 \\
& $36-40$ & 2.1 \\
Gender & $40-$ above & 2.8 \\
\multirow{3}{*}{ Education } & Male & 93.1 \\
& Female & 6.9 \\
\multirow{3}{*}{ Department } & Bachelors & 32.6 \\
& Master & 65.3 \\
Tenure & M.S & 2.1 \\
& Marketing & 54.2 \\
& HRM & 10.4 \\
& Finance & 35.4 \\
& $1-5$ & 64.6 \\
\hline
\end{tabular}

Table 2. Correlation analysis

\begin{tabular}{llll}
\hline & Job performance & Job Satisfaction & Job design \\
\hline Job performance & 1 & $.619^{* *}$ & $0.390^{* *}$ \\
Job satisfaction & 150 & 1 & $.492^{* *}$ \\
Job design & 150 & 150 & 1 \\
\hline
\end{tabular}

$\mathrm{Ns}=$ not significant $(\mathrm{p}>.05),{ }^{*} \mathrm{p}<.05,{ }^{* *} \mathrm{p}<.01,{ }^{* * *} \mathrm{p}<.001$.

Table 3. Mediation

\begin{tabular}{llllll}
\hline Predictor & $\mathrm{B}$ & $\mathrm{R}^{2}$ & $\mathrm{Sig}$ & $\mathrm{T}$ & $\mathrm{F}$ \\
\hline $\mathrm{J} . \mathrm{D} \longrightarrow \mathrm{J} . \mathrm{P}$ & 0.587 & 0.242 & 0.008 & 6.730 & 45.287 \\
$\mathrm{~J} . \mathrm{D} \longrightarrow \mathrm{J} . \mathrm{S}$ & 0.767 & 0.384 & 0.014 & 9.40 & 88.436 \\
$\mathrm{~J} . \mathrm{S} \longrightarrow \mathrm{J} . \mathrm{P}$ & 0.376 & 0.152 & 0.003 & 5.053 & 25.530 \\
$\mathrm{~J} . \mathrm{D} \longrightarrow \mathrm{J} . \mathrm{S} \longrightarrow \mathrm{J} . \mathrm{P}$ & -.108 & .31 & .300 & -1.04 & 64.16 \\
\hline
\end{tabular}

\section{Findings and Discussion}

It is generally perceived that employees and employers both do not consider job design and the concept is not implementing in Pakistani organizations, in a country like Pakistan where the unemployment rate is increasing 
day by day and inflation rate is $10.2 \%$ (trading economics, 2011) the most important motivating factor is monetary rewards instead of growth in career and, to some extend it is factual, but the work environment is changing very rapidly, and it has affected the trends in Pakistani organizational cultures. It is observed that people are keen to learn and grow, they are asking for freedom in work related decisions, trying to polish their skills with trainings and development courses and exposure, though the ratio is low but it is increasing with the passage of time.

Our research outcomes show that job design has sufficient role in employee satisfaction and performance in FMCG industry of Pakistani. Practically organizations have to adapt to cultural patterns of the host country similarly, the multinationals operating in Pakistan have modified their organizational norms and processes as well. In a collectivist society like Pakistan people do prefer jobs with significance and autonomy, highest of the responses depict that people prefer to have autonomy in their work, which is the self-determination in accomplishing tasks. Job autonomy refers to the degree any worker has liberty to plan his or her tasks, take decisions according to the situation and find out all those means to achieve their work objectives.

\section{Limitations and Future Direction}

The present research has attempted to analyze the impact of job design on employee performance and the mediating role of the job satisfaction. In order to accomplish it, data was collected from FMCG s sectors employees within two cities Rawalpindi and Islamabad of Pakistan. But future research can be preceded in other cities of Pakistan. Furthermore, the model can be tested with other mediating variables like motivation etc. As the main respondents were middle level employees but the research can be proceed with respondents of 1 st line and executives level managers.

\section{Conclusion}

Since the start of management literature the topic of job design has been under discussion. However there has always been raised about the suitable way of job design. Hackman and Oldham paved ways to research in the field of job design and this theory has been used for more than 35 years. An effort to identify its impact in Pakistan was carried out and the paper recommends that management of any organization must consider employee's perspective in designing job description of each position and emphasis should be on JCM elements the job related concepts in the given society.

\section{References}

Adler, N. J. (1991). International Dimensions of Organizational Behavior (2nd ed.). PWS-Kent, Boston, MA.

Baird, L., \& Kram, K. (1983). Career Dynamics: Managing the Superior/Subordinate Relationship. Organizational Dynamics, 11(3), 46-64. http://dx.doi.org/10.1016/0090-2616(83) 90038-4

Baron, R. M., \& Kenny, D. A. (1986). The moderator-mediator variable distinction in social psychological research: conceptual, strategic, and statistical considerations. J. Pers. Soc. Psychol., 51(6), 1173-1182. http://dx.doi.org/10.1037/0022-3514.51.6.1173

Bassey, M. (2002). Motivation and work: investigation and analysis of motivational factors at Work. Research in Organizational Behavior, 16(1), 250-79.

Bedeian, A. G., \& Armenakis, A. A. (1981). A path-analytic study of the consequences of role conflict and ambiguity. Academy of Management Journal, 2(4), 417-24. http://dx.doi.org/10.2307/255852

Blackwell, J. R., \& Newell, K. M. (1996). The informational role of knowledge of results in motor learning. Acta Psychologica, 92, 119-129. http://dx.doi.org/10.1016/0001-6918(95) 00013-5

Brian T. L., \& Raymond, A. N., Nancy, L. M., \&Michael, P. F. (1985). A Meta-Analysis of the Relation of Job Characteristics to Job Satisfaction. European Journal of Work and Organizational Psychology, 9(1), $79-110$.

Campbell, J. P. (1990). Modeling the performance prediction problem in industrial and organizational psychology. In M. D. Dunnette \& L. M. Hough (Eds.), Handbook of industrial and organizational sychology, 11(2), 688-732.

Daniel, J. B. (1981). Structural Relationships, Job Characteristics, and Worker Satisfaction and Performance. Administrative Science Quarterly, 26(3), 331-348. http://dx.doi.org/10.2307/2392511

Dwyer, D. J., Schwartz, R. H., \& Fox, M. L. (1992). Decision-making autonomy in nursing. Journal of Nursing Administration, 22, 17-23. http://dx.doi.org/10.1097/00005110-199202000-00020

Elkins, T. J., \& Phillips, J. S. (2000). Job context, selection decision outcome, and the perceived. Journal of 
Applied Psychology, 85(3), 479-484. http://dx.doi.org/10.1037/0021-9010.85.3.479

Feldman, D. C., \& David, C. T. (1992). Career Man- agreement Issues Facing Expatriates. Journal of International Business Studies, second quarter, 2(1), 271-293.

Flaherty \& Pappas. (2002). The Influence of Career Stage on Job Attitude: Toward a Contingency Perspective. Journal of Personal Selling \& Sales Management, 22(3), 1-16.

Fried, Y., \& Ferris, G. R. (1987). The validity of the job characteristics model: a review and Meta-analysis. Organizational Behavior and Human Performance, 16, 250-79.

Gardner, D. G. (1986). Activation theory and task design: An empirical test of several new predictions. Journal of Applied Psychology, 71, 411-418. http://dx.doi.org/10.1037/0021-9010.71.3.411

Geister, S., Konradt, U., \& Hertel, G. (2006). Effects of process feedback on motivation, satisfaction and performance in virtual teams. Small Group Research, 37(5), 459-489. http://dx.doi.org/10.1177/1046496406292337

Gerhart, B. (1987). How important are dispositional factors as determinants of job satisfaction? Implications for job design and other personnel programs. Journal of Applied Psychology, 72, 366-73. http://dx.doi.org/10.1037/0021-9010.72.3.366

Gilbreth, F. B. (1911). Motion Study, Van Nostrand. Princeton, NJ.

Glisson, C., \& Durick, M. (1988). Predictors of job satisfaction and organization commitment in human service organizations. Administrative Science Quarterly, 3(3), 61-81. http://dx.doi.org/10.2307/2392855

Grag, P., \& Rastogi, R. (2005). A New Model for Job Design: Motivating employee's Performance. Journal of Management Development, 25(6), 572-587. http://dx.doi.org/10.1108/02621710610670137

Grant, A. M. (2007). Relational job design and motivation. Academy of Management Review, 32(2), 393-417. http://dx.doi.org/10.5465/AMR.2007.24351328

Griffin, R. W. (1987). Toward an integrated theory of task. Research in Organizational Behavior, 9, 79-120.

Hackman, J. R. (1980). Work redesign and motivation. Professional Psychology: Research and Practice, 11, 445-455. http://dx.doi.org/10.1037/0735-7028.11.3.445

Hackman, J. R., \& Oldham, G. R. (1975). Development of the job diagnostic survey. Journal of Applied Psychology, 60, 159-170. http://dx.doi.org/10.1037/h0076546

Hackman, J. R., \& Oldham, R. G. (1976). Motivation through the design of work: test of atheory. Organizational Behavior and Human Performance, 16, 250-79. http://dx.doi.org/10.1016/0030-5073(76)90016-7

Herzberg, F., Mausner, B., \& Snyderman, B. (1959). The Motivation to Work. NewYork, NY: Wiley.

Huselid, A., Becker, M. (1997). The impact of high performance work systems, implementation effectiveness. Academy of Management Best Papers Proceedings, 144-148.

Hyatt, T. A., \& Prawitt, D. F. (2011). Does Congruence between Audit Structure and Auditors' Locus of Control Affect Job Performance. The Accounting Review, 76(2), 263-274. http://dx.doi.org/10.2308/accr.2001.76.2.263

Janssen. (2001). Fairness Perceptions as a Moderator in the Curvilinear Relationships Between Job Demands, Job performance and job satisfaction. Academy of Management Journal, 44(5), 1039-1050. http://dx.doi.org/10.2307/3069447

Kluger, A. N., \& DeNisi, A. (1996). The effects of feedback interventions on performance: a historical review, a meta-analysis, and a preliminary feedback intervention theory. Psychological Bulletin, 119(2), 254-84. http://dx.doi.org/10.1037/0033-2909.119.2.254

Kopelman, R. E. (1986). Managing Productivity in Organizations: A Practical. People-Oriented Perspective. New York: McGraw-Hill.

Kouzes, J., \& Posner, M. (1995). The leadership challenge: How to keep getting extraordinary things done in organizations (Rev. ed.). San Francisco: Jossey-Bass.

Lam, S. S. K., Yik, M. S. M., \& Schaubroeck, J. (2002). Responses to formal performance appraisal feedback: the role of negative affectivity. Journal of Applied Psychology, 87(1), 192-201. http://dx.doi.org/10.1037/0021-9010.87.1.192

Lawler, E. E., Mohrman, S. A., \& Ledford, G. E. (1995). Creating high performance organizations: Practices and 
results of employee involvement and total quality management in Fortune 1000 companies. SanFrancisco: Jossey-Bass. International Journal of Psychology, 20(2), 207-219.

Li , F., Li, Y., \& Erping, E. (2009). Task Characteristics and Team Performance: the Mediating Effect of Team Member Satisfaction. Social Behavior and Personality, 37(10), 1373-1382. http://dx.doi.org/10.2224/sbp.2009.37.10.1373

Locke, E. A. (1976). The nature and causes of job satisfaction. Handbook of industrial and organizational psychology, 1297-1349. http://dx.doi.org/10.1037/0033-2909.90.1.125

Locke, E., Shaw, K., Saari, L., \& Latham, G. (1981). Goal-setting and task performance: 1969-1980. Psychological Bulletin, 90, 125-152.

Love, P. E. D., \& Edwards, D. J. (2005). Taking the pulse of UK construction project managers' health: influence of job demands, job control and social support on psychological well-being. Engineering, Construction, and Architectural Management, 12(1), 88-101. http://dx.doi.org/10.1108/09699980510576916

Lowry, P. E. (1994). Selection methods: comparison of assessment centers with personnel records evaluations. Public Personnel Management, 23(3), 383-95.

Mausolef, C. (2004). Learning from Feedback in Performance Measurement Systems. Public Performance \& Management Review, 28(1), 9-29.

Mohrman, \& Ledford. (1995). Job design, opportunities for skill utilization, and intrinsic job satisfaction. European Journal of Work and Organizational Psychology, 14(1), 59-79.

Motowidlo, S. J., Borman, W. C., \& Schmit, M. J. (1997). A theory of individual differences in task and contextual performance. Human Performance, 10, 71-83. http://dx.doi.org/10.1207/s15327043hup1002_1

Mueller, B. P. (1994). Do Supervisors and Subordinate and See Eye to Eye on Job Enrichment. Journal of Business and Psychology, 13(2).

Nancy G. D., \& Danial, C. G. (1996). Human Resource Nature Shape our Choices Journal of Organizational Behavior, 17 , $329-347$. http://dx.doi.org/10.1002/(SICI)1099-1379(199607)17:4<329::AID-JOB754>3.0.CO;2-B

Niazi, A. S. (2011). Training and Development Strategy and Its Role in Organizational Performance. Journal of Public Administration and Governance, 2(1), 2161-7104.

Orpen, C. (1985). The effects of need for achievement and need for independence on the relationship between perceived job attributes and managerial satisfaction and performance. Human Resource International. 40(2), 292-312.

Pentland, B. T. (2003). Sequential Variety in Work Processes Author. Reviewed work(s) Organization Science, 14(5), 528-540. http://dx.doi.org/10.1287/orsc.14.5.528.16760

Peter, C. (1993). Are Skill Requirements Rising? Evidence from Production and Clerical. Industrial and Labor Relations Review, 46(3), 515-530. http://dx.doi.org/10.2307/2524550

Price, J., \& Mueller, C. (1986). Absenteeism and turnover among hospital employees. Greenwich, CT: JAI. http://dx.doi.org/10.1111/j.1744-6570.1987.tb00605.x

Price, J., Fried, Y., \& Ferris, G. R. (1987). The validity of the job characteristics model: A review and meta-analysis. Personnel Psychology, 40(2), 287-322.

Ryan, A. M., Schmit, J. M., \& Jhonson, J. (1996). Attitudes and effectiveness: Examining relations at an $\begin{array}{lllll}\text { organizational level. Psychology, } & \text { 89, }\end{array}$ http://dx.doi.org/10.1111/j.1744-6570.1996.tb02452.x

Spreitzer, G. M. (1999). Psychological empowerment in the workplace: dimensions, measurement, and validation. Academy of Management Journal, 38, 1442-65. http://dx.doi.org/10.2307/256865

Statistic Beauro of Pakistan. (2013). Inflation rate of Pakistan: Cpi index. Retrieved form http://www.tradingeconomics.com/pakistan/inflation/cpi

Taber, T. D., \& Taylor, E. (1990). A review and evaluation of the psychometric properties of the Job Diagnostic Survey. Personnel Psychology, 43, 467-497. http://dx.doi.org/10.1111/j.1744-6570.1990.tb02393.x

Tanner, M. (1998). Self-managed groups do it for Do-It-All. Human Resource International Digest, 6(4), 12-32. 
Taylor, F. W. (1947). The Principles of Scientific Management. New York, NY: Harper and Brothers.

Weiss, H. M. (2002). Deconstructing job satisfaction separating evaluations, beliefs and affective experiences. Human Resources Management Review, 12, 173-194. http://dx.doi.org/10.1016/S1053-4822 (02)00045-1

\section{Copyrights}

Copyright for this article is retained by the author(s), with first publication rights granted to the journal.

This is an open-access article distributed under the terms and conditions of the Creative Commons Attribution license (http://creativecommons.org/licenses/by/3.0/). 